\title{
A New Thinking of Loyalty for a Travel Product
}

\author{
Pan Ying-Jen, Wang Yi-Fong \\ Southern Taiwan University of Science and Technology, Tainan City, Taiwan
}

Liu Min-Hsiung

Taipei College of Maritime Technology, Taipei City, Taiwan

\begin{abstract}
Loyalty has been defined in overly simple ways especially for travel products in tourism setting. The aim of this study is to find out and identify the loyalty perceptions of a travel product. A group package tour (GPT) is selected to represent the travel product in this study for its covering diversified types of travel products, such as adventure package tours, recreational package tours, and other themed package tours, which can fit in with many travel settings. Structural equation modeling (SEM) was employed to test the research data and conceptual framework. The research findings show that, unlike tangible products, service products such as a GPT could have two different loyalty perceptions, namely, loyalty of the travel agency (brand) and loyalty of the product category.
\end{abstract}

Keywords: group package tour (GPT), satisfaction, brand, loyalty, product category

\section{Introduction}

As a result of worldwide economic growth and expanding disposable personal income, traveling has become a part of life for many people. This has led to the development of the world's largest industry, the tourism industry. In a highly competitive industry such as tourism, the provision of high satisfactory products is a major source of sustainable competitive advantage (Chen, 2008). Improvement in tourist perception of satisfaction can lead to favorable outcomes desired by travel agencies (Cronin, Brady, \& Hult, 2000; He \& Song, 2009), such as tourist's loyalty.

Satisfaction serves as a strong predictor of post-purchase behavioral intentions (Cronin et al., 2000; Williams \& Soutar, 2009). A thorough analysis of the linkages between satisfaction and behavioral intentions is the only way to derive the whole consumption experience, even in a tourism setting. Moreover, understanding the nature of travel is only possible through designing research that considers the specific characteristics of the travel product (Jen \& Hu, 2003; Ricci \& Missier, 2004). A group package tour (GPT) is selected to represent travel products for two reasons. First, GPTs include many diversified types of travel products such as adventure package tours, recreational package tours, and other themed package tours, which can fit in with many travel settings. Second, the GPT travel mode retains its greatest popularity especially in Asian countries (Fuller, 1994; Goldsmith, Flynn, \& Bonn, 1994).

Pan Ying-Jen, assistant professor, Department of Leisure, Recreation, and Tourism Management, Southern Taiwan University of Science and Technology. Email: irvingpan@mail.stust.edu.tw.

Wang Yi-Fong, associate professor, Department of Leisure, Recreation, and Tourism Management, Southern Taiwan University of Science and Technology.

Liu Min-Hsiung, assistant professor, Department of Marine Leisure and Tourism, Taipei College of Maritime Technology. 


\section{Theoretical Background}

\section{Satisfaction and Its Relationships With Loyalty}

Loyalty is always measured by consumers' repurchase intentions and recommending behaviors (Zeithaml, Berry, \& Parasuraman, 1996). It can also be called positive behavioral intentions (Cronin et al., 2000). Research studies have established the consequent relationships between consumer perceptions of satisfaction and behavioral intentions (Cronin et al., 2000; Oh, 1999; Petrick \& Backman, 2002; Zeithaml et al., 1996). Consumers decide their future behaviors by assessing previous satisfaction, and there are two main consequences of satisfaction, which are intention to repurchase and positive recommendation (Cronin et al., 2000). Behavioral intentions refer to consumers repurchasing the goods or services in the same shop (repurchase intention) and delivering their user experiences to friends and relatives (recommending behavior) (Cronin et al., 2000; Zeithaml et al., 1996). Zeithaml et al. (1996) indicated that repurchase intention refers to a customer's intention to remain loyal to a service provider and repurchase from them. In this research, repurchase intention is defined as a tourist's intention to travel with a GPT organized by the same travel agency or any GPT in general. Previous studies on choice of tour packages have shown that one of the reasons for choosing a travel product is friends' recommendations (Quiroga, 1990) and that tourists tend to look for information and salient cues to help them evaluate alternative product offerings (Tsaur \& Wang, 2009). Zeithaml et al. (1996) described recommending behavior as customers saying positive things about a service provider and recommending them to other consumers. Accordingly, recommending behavior is defined in the current research as a tourist's behavior in spreading positive word of mouth and recommending to others a GPT organized by the same travel agency or any GPT in general. In this study, loyalty is expressed into two different settings and measured by Repurchase and Recommend separately due to the nature of the travel product. The justification is stated in the later section.

\section{Loyalty of the Brand or Product Category}

Guest (1944) indicated that there are two different ways to consider loyalty (behavioral intentions). The first is to consider whether there is brand loyalty for a whole product category, i.e., are people loyal to all brands of a product in general? In the second place, is there loyalty exhibited towards some specific brands of a product? The two types of loyalty are considered relevant to this study, as the loyalty to a GPT might also occur in the same situations. In general, brand loyalty has been defined in overly simple ways (Jacoby, 1971). For example, empirical results suggest that a consumer is often loyal to many brands in a product category (this study refers to GPTs). The possibility is that individuals may be loyal to more than one brand in a product category (Jacoby, 1971).

Chaudhuri and Holbrook (2001) indicated that product category characteristics will influence brand choice decisions. Hedonic and utilitarian values can be viewed as representing two types of knowledge gathered from prior experience with the product category. Their results show that the consumers focus more on the hedonic value of the product category, and this focus results in loyalty to the brand. This is because when the emotional element of pleasure is high and positive for a product category, consumers experience more enjoyable effects from the brand consumed. The utilitarian value of the product category is not related to brand loyalty. If consumers focus more on the utilitarian value, then the brand is not a concern, but the product category characteristics are. In a GPT setting, when selecting a package, tourists pay more attention to the functional effects such as price (Zeithaml, 1988), convenience, saving time and effort (Overby \& Lee, 2006); they might 
be loyal to the product category only and have no regard to brands. Travel products are organized by the tour provider, who integrates different products and services into one package. Hence, in the tourism setting, it is appropriate to think of the tour provider as the brand. In sum, the behavioral intentions (loyalty) based on the arguments stated above will have two settings, one for the same tour provider/travel agency (brand) and the other for the generic benefits that a GPT can offer (product category).

Many studies of satisfaction (Cronin et al., 2000; Ha \& Jang, 2009; Kuo, Wu, \& Deng, 2009; Ryu, Han, \& Kim, 2008) have indicated a positive relationship between consumer satisfaction and behavioral intentions. These studies show that satisfaction has a positive effect on repurchase and recommendation. Studies of people's choices of package tour have shown that the main reason for choosing a travel package is friends' recommendations (Quiroga, 1990). Package travelers prefer to leave their arrangements to a travel agency, because the convenience of one-time arrangement, well-developed entertainment, and guided tours that enable them to see all the sights are only available in package tour (Hsieh, O’Leary, \& Morrison, 1994). Heung and Chu (2000) indicated that tourists satisfied with the GPT would tend to recommend the GPT to their friends for its service offerings and benefits. Studies also show that tourists care less about brands (Chang, 2006; Wang, Chou, Su, \& Tsai, 2007) but are more price and content driven (Chang, 2006; Dwyer, Forsyth, \& Rao, 2000; Heung \& Chu, 2000; Tsaur \& Wang, 2009). Hence, according to the arguments above, it is hypothesized that (see Figure 1):

H1: Satisfaction has a positive effect on the repurchase of a GPT organized by the same travel agency.

H2: Satisfaction has a positive effect on the recommendation of a GPT organized by the same travel agency.

H3: Satisfaction with a GPT will lead to the repurchase of any GPT.

H4: Satisfaction with a GPT will lead to the recommendation of any GPT.

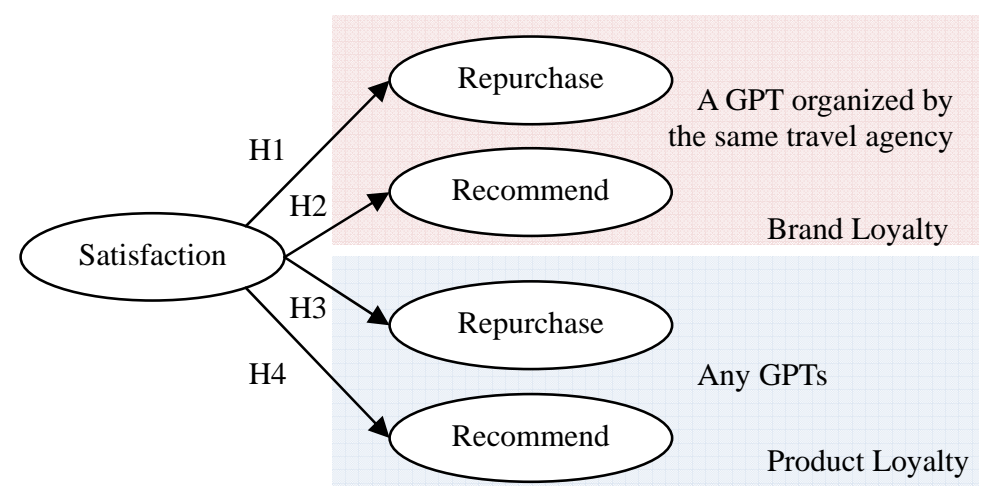

Figure 1. Conceptual framework.

\section{Research Methods}

In order to test the conceptual framework, five latent constructs are created, namely, satisfaction and four behavioral intention constructs. The definition and scale items of satisfaction were adopted from Oliver (2010) and were modified into a GPT setting as a tourist's perception that a GPT provides a pleasurable level of consumption-related fulfillment. The measurement scales of Repurchase and Recommend were modified from Zeithaml et al. (1996) and Cronin et al. (2000). Four items were used for each construct and modified into two different loyalty settings. All the measurement scales are reflective indicators. 
A 7-point Likert scale questionnaire was used for the purpose of obtaining the depth of information from respondents. In total, 561 GPT tourists were surveyed at the end of their tours. Comrey and Lee (1992) suggested that a sample size of 500 is very good for that structural equation models require a fairly large sample size in order to be analyzed effectively (Hair, 2010; Tabachnick \& Fidell, 1996). Hence, the sample size of this study meets the requirements suggested by structural equation modeling (SEM) experts.

A two-phase approach suggested by Anderson and Gerbing (1988) was employed for SEM analysis. The assessment of measurement scales (confirmatory factor analysis) was analyzed before testing the structural model. Before analyzing the collected data, the normality test was conducted to ensure that the observed variables in the model are normally distributed. In addition, the result of the detection of common method variance (CMV) also shows that there is no sign for CMV problem. Both measurement and structural models were assessed using Amos 18.0 software.

\section{Research Findings}

The findings of this study are summarized in two key issues. First, the statistic results of both measurement and structural models are stated. Second, the results of the casual relationships of each construct are presented. The estimating parameter of maximum likelihood (ML) is used for assessment of the measurement and structural models. The results show that both measurement and structural models pass the goodness-of-fit (GOF) indices, indicating that the research model is valid for path estimate of the hypotheses (see Table 1).

Table 1

GOF Values of the Research Model

\begin{tabular}{|c|c|c|c|c|c|}
\hline Statistic & Index & Measurement model & Structural model & Cutoff value & GOF result \\
\hline \multirow{3}{*}{ Absolute fit indices } & $\chi^{2}$ & 0.000 & 0.000 & $\begin{array}{l}\text { Significant } p \text {-value } \\
\text { due to large sample }\end{array}$ & Expected \\
\hline & $\chi^{2}: \mathrm{df}$ & 3.0353 & 3.640 & 2 to 5 & Satisfied \\
\hline & RMSEA & 0.06 & 0.069 & $<0.07$ & Satisfied \\
\hline \multirow{3}{*}{$\begin{array}{l}\text { Incremental fit } \\
\text { indices }\end{array}$} & CFI & 0.941 & 0.921 & $>0.90$ & Satisfied \\
\hline & TLI & 0.935 & 0.915 & $>0.90$ & Satisfied \\
\hline & IFI & 0.941 & 0.921 & $>0.90$ & Satisfied \\
\hline \multirow{2}{*}{$\begin{array}{l}\text { Parsimony fit } \\
\text { indices }\end{array}$} & PNFI & 0.831 & 0.835 & $>0.50$ & Satisfied \\
\hline & PGFI & 0.708 & 0.698 & $>0.50$ & Satisfied \\
\hline
\end{tabular}

Notes. RMSEA $=$ Root Mean Square Error of Approximation. CFI = Comparative Fit Index. TLI $=$ Tucker Lewis Index. IFI = Incremental Fit Index. PNFI = Parsimony Normed Fit Index. PGFI = Parsimony Goodness-of-Fit Index.

The results in Table 2 show that satisfaction has significant and positive relationships with four loyalty constructs. This further indicates that the four hypotheses carried out in this study are all supported. The results show that satisfaction has positive effects on the four loyalty constructs: repurchase a GPT organized by the same travel agency, recommend a GPT organized by the same travel agency, repurchase any GPT, and recommend any GPT. Within these four constructs, satisfaction has the greatest effect on repurchase of a GPT organized by the same travel agency. The findings are consistent with He and Song's (2009) research that tourist satisfaction leads to future repurchase intentions for a packaged tour. 
Table 2

Regression Weights of the Research Model

\begin{tabular}{|c|c|c|c|}
\hline \multirow{2}{*}{ Construct/path/construct } & \multicolumn{3}{|c|}{ Regression weight (coefficients) } \\
\hline & Unstandardized loadings & Standardized loadings & $p$-value \\
\hline $\mathrm{SA} \rightarrow \mathrm{RP}$ (same TA) & 0.548 & 0.623 & $* * *$ \\
\hline $\mathrm{SA} \rightarrow \mathrm{RC}$ (same TA) & 0.077 & 0.090 & $0.004^{* *}$ \\
\hline $\mathrm{SA} \rightarrow \mathrm{RP}($ any $\mathrm{GPT})$ & 0.298 & 0.312 & $* * *$ \\
\hline SA $\rightarrow$ RC (any GPT) & 0.163 & 0.208 & $* * *$ \\
\hline
\end{tabular}

\section{Conclusion and Implications}

All the four hypotheses are supported by the empirical data. Based on Guest (1944) and Chaudhuri and Holbrook (2001), the tourist does have two loyalty decisions: The first is loyalty to brand, and the other is loyalty to the product category. Loyalty is divided into two scenarios: That a tourist is loyal to a travel agency (brand) or to any GPT (product category) is justified through literature and confirmed by the empirical data.

Among the behavioral intention constructs, tourist satisfaction has the greatest effect on repurchase of a GPT organized by the same travel agency, indicating that tourists are loyal to their travel agencies. This implies that satisfaction is the key to retaining customers and building loyalty. For repurchase intentions, satisfaction has a greater effect on repurchase of a GPT organized by the same travel agency than on repurchase of any GPT. This indicates that, in repurchase intentions, GPT tourists are loyal to their travel agencies (brand). In terms of recommendations, satisfaction has a greater effect on recommendation of any GPT than a GPT organized by the same travel agency. This indicates that, in recommending behaviors, GPT tourists are loyal to any GPT (product category). This can be explained by postulating that tourists are willing to repurchase from their trusted travel agencies but would recommend any GPT to their friends as a preferred alternative to traveling independently.

\section{References}

Anderson, J., \& Gerbing, D. (1988). Structural equation modeling in practice: A review and recommended two-step approach. Psychological Bulletin, 103(3), 411-423.

Chang, J. C. (2006). Customer satisfaction with tour leaders’ performance: A study of Taiwan's package tours. Asia Pacific Journal of Tourism Research, 11(1), 97-116.

Chaudhuri, A., \& Holbrook, M. B. (2001). The chain of effects from brand trust and brand affect to brand performance: The role of brand loyalty. Journal of Marketing, 65(2), 81-93.

Chen, C. F. (2008). Investigating structural relationships between service quality, perceived value, satisfaction, and behavioral intentions for air passengers: Evidence from Taiwan. Transportation Research Part A: Policy and Practice, 42(4), 709-717.

Comrey, A. L., \& Lee, H. B. (1992). A first course in factor analysis. Hillsdale, N.J.: Lawrence Erlbaum Associates.

Cronin, J. J., Brady, M. K., \& Hult, G. T. M. (2000). Assessing the effects of quality, value, and customer satisfaction on consumer behavioral intentions in service environments. Journal of Retailing, 76(2), 193-218.

Dwyer, L., Forsyth, P., \& Rao, P. (2000). Price competitiveness of tourism packages to Australia: Beyond the "big Mac” index. Asia Pacific Journal of Tourism Research, 5(2), 50-56.

Fuller, G. (1994). Travel agency management. Cincinnati, Ohio: South Western Publishing Co..

Goldsmith, R. E., Flynn, L. R., \& Bonn, M. (1994). An empirical study of heavy users of travel agencies. Journal of Travel Research, 33(1), 38-43.

Guest, L. (1944). A study of brand loyalty. Journal of Applied Psychology, 28(1), 16-27.

Ha, J., \& Jang, S. (2009). Perceived values, satisfaction, and behavioral intentions: The role of familiarity in Korean restaurants. International Journal of Hospitality Management, 29(1), 2-13. 
Hair, J. F. (2010). Multivariate data analysis (7th ed.). Upper Saddle River, N.J.: Prentice Hall.

He, Y., \& Song, H. (2009). A mediation model of tourists' repurchase intentions for packaged tour services. Journal of Travel Research, 47(3), 317-331.

Heung, V. C. S., \& Chu, R. (2000). Important factors affecting Hong Kong consumers’ choice of a travel agency for all-inclusive package tours. Journal of Travel Research, 39(1), 52-59.

Hsieh, S., O’Leary, J. T., \& Morrison, A. M. (1994). A comparison of package and non-package travelers from the United Kingdom. Journal of International Consumer Marketing, 6(3), 79-100.

Jacoby, J. (1971). A model of multi-brand loyalty. Journal of Advertising Research, 11(3), 25-31.

Jen, W., \& Hu, K. C. (2003). Application of perceived value model to identify factors affecting passengers' repurchase intentions on city bus: A case of the Taipei metropolitan area. Transportation Research Part A: General, 30(3), 307-327.

Kuo, Y. F., Wu, C. M., \& Deng, W. J. (2009). The relationships among service quality, perceived value, customer satisfaction, and post-purchase intention in mobile value-added services. Computers in Human Behavior, 25(4), 887-896.

Oh, H. (1999). Service quality, customer satisfaction, and customer value: A holistic perspective. International Journal of Hospitality Management, 18(1), 67-82.

Oliver, R. L. (2010). Satisfaction: A behavioral perspective on the consumer. Armonk, N.Y.: M. E. Sharpe.

Overby, J. W., \& Lee, E. J. (2006). The effects of utilitarian and hedonic online shopping value on consumer preference and intentions. Journal of Business Research, 59(10-11), 1160-1166.

Petrick, J. F., \& Backman, S. J. (2002). An examination of the construct of perceived value for the prediction of golf travelers' intentions to revisit. Journal of Travel Research, 41(1), 38-45.

Quiroga, I. (1990). Characteristics of package tours in Europe. Annals of Tourism Research, 17(2), 185-207.

Ricci, F., \& Missier, F. D. (2004). Supporting travel decision making through personalized recommendation. In C. M. Karat, J. O. Blom, \& J. Karat (Eds.), Designing personalized user experiences in ecommerce (pp. 231-251). Kluwer Academic Publishers.

Ryu, K., Han, H., \& Kim, T. H. (2008). The relationships among overall quick-casual restaurant image, perceived value, customer satisfaction, and behavioral intentions. International Journal of Hospitality Management, 27(3), 459-469.

Tabachnick, B. G., \& Fidell, L. S. (1996). Using multivariate statistics. New York, N.Y.: HarperCollins College Publishers.

Tsaur, S. H., \& Wang, C. H. (2009). Tip-collection strategies, service guarantees, and consumer evaluations of group package tours. Journal of Travel Research, 47(4), 523-534.

Wang, K. C., Chou, S. H., Su, C. J., \& Tsai, H. Y. (2007). More information, stronger effectiveness? Different group package tour advertising components on web page. Journal of Business Research, 60(4), 382-387.

Williams, P., \& Soutar, G. N. (2009). Value, satisfaction, and behavioral intentions in an adventure tourism context. Annals of Tourism Research, 36(3), 413-438.

Zeithaml, V. A. (1988). Consumer perceptions of price, quality, and value: A means-end model and synthesis of evidence. Journal of Marketing, 52(3), 2-22.

Zeithaml, V. A., Berry, L. L., \& Parasuraman, A. (1996). The behavioral consequences of service quality. Journal of Marketing, 60(2), 31-46. 